\title{
PENDIDIKAN ANAK SUPERNORMAL DENGAN PENDEKATAN LIVING VALUES EDUCATION PROGRAM (STUDI KASUS KELAS AKSELERASI MAN 2 KOTA MADIUN)
}

\author{
Asfahani \\ Institut Agama Islam Sunan Giri Ponorogo \\ fahan380@gmail.com \\ Wiwin Rif'atul Fauziyati \\ Institut Agama Islam Sunan Giri Ponorogo \\ rivaat_bik@yahoo.com
}

\begin{abstract}
The purpose of this study was to determine the strategies, approaches, stages and results of the living value education program in the education of supernormal children in MAN 2 Madiun City. Qualitative research method was conducted by direct observation and gained the results of this study which were that the Living Values Education Program (LVEP) acceleration class of MAN 2 in Madiun City is done by habituation, lecture, hands-on practice, discussion, performance, assignments, and visits to religious places, and acts as good role model. The holistic approach (integrated and synchronized) in which the development of character values is integrated and interconnected in all aspects of the madrasa environment. The stages of reviving the value in children accelerated starting with the quarantine process. Through this LVEP, it is certain that children have personalities based on religious and cultural noble values. The conclusion of this research is that the LVEP approach has delivered supernormal children of MAN 2 Madiun City to have an awareness of high values, virtuous character and aware of the importance of exemplary and practice of values themselves in appreciating "good value" in children, as well as reflect on it.
\end{abstract}

Keywords: Value and Value Education, Living Values Education Program, Supernormal Children.

Abstrak
Tujuan dari penelitian ini adalah untuk mengetahui strategi, pendekatan,
tahapan dan hasil program pendidikan nilai kehidupan dalam pendidikan anak-
anak supernormal di MAN 2 Kota Madiun. Metode penelitian kualitatif
dilakukan dengan observasi langsung dan diperoleh hasil penelitian ini yaitu
bahwa kelas akselerasi Living Values Education Program (LVEP) MAN 2 di
Kota Madiun dilakukan dengan pembiasaan, kuliah, praktik langsung, diskusi,
kinerja, tugas, dan kunjungan ke tempat-tempat relijius, dan uswah hasanah.
Pendekatan holistik (terintegrasi dan tersinkronisasi) di mana pengembangan
nilai karakter terintegrasi dan saling berhubungan dalam semua aspek 
lingkungan madrasah. Tahapan menghidupkan kembali nilai pada anak dimulai dengan proses karantina. Melalui LVEP ini, dapat dipastikan bahwa anak-anak memiliki kepribadian berdasarkan nilai-nilai luhur agama dan budaya. Kesimpulan dari penelitian ini adalah bahwa pendekatan LVEP telah menjadikan anak-anak supernormal dari MAN 2 Kota Madiun untuk memiliki kesadaran akan nilai-nilai tinggi, karakter berbudi luhur dan menyadari pentingnya teladan dan praktik nilai-nilai itu sendiri dalam menghargai "nilai baik" pada anak.

Kata kunci: Nilai dan Pendidikan Nilai, Program Pendidikan Living Values, Anak Supernormal

\section{Pendahuluan}

Dalam menghadapi kemajuan ilmu pengetahuan dan teknologi, bangsa Indonesia harus meningkatkan kualitas sumber daya manusia (SDM) agar mampu mengikuti kemajuan tersebut. SDM yang berkualitas adalah berkembangnya manusia secara menyeluruh. Manusia yang berkualitas adalah manusia yang berkembang optimal baik secara fisik, kognitif, emosi, sosial, maupun spiritual. Di sisi lain, di antara bangsa Indonesia terdapat anak-anak yang memiliki kecerdasan luar biasa atau bisa dikatakan anak supernormal.

Anak supernormal memiliki keunggulan-keunggulan berbeda dengan anak normal. Dari segi fisik sedikit lebih unggul baik tinggi, bobot dan kesehatan. Lebih mampu berkonsentrasi dalam waktu yang relatif lama, mampu mencipta, mampu memahami mulai dari masalah material sampai masalah abstrak. Karena kelebihan dalam hal kecerdasan, maka cenderung bergaul dengan anak-anak yang lebih tua yang lebih banyak memiliki kemahiran fisik dan pengalaman. ${ }^{1}$

Keunggulan-keunggulan yang dimiliki anak supernormal sangat penting untuk dikembangkan dan dibimbing secara optimal. Karena anak yang memiliki kecerdasan lebih laksana tanaman yang membutuhkan seseorang yang dapat membimbing dan membantunya agar ia bisa tumbuh dan berkembang secara alamiah, menghilangkan berbagai kendala yang ada di

\footnotetext{
${ }^{1}$ Ma'ruf Zurayk, Aku dan Anakku Bimbingan Praktis Mendidik Anak Menuju Remaja (Bandung: Al-Bayan, 1998),76
} 
hadapannya, serta merintis jalan baginya. Mereka membutuhkan orang yang dapat memahami serta menghargai kelebihannya secara utuh.

Apabila anak supernormal tidak disediakan pelayanan pendidikan, tidak dibimbing dan tidak dididik sesuai dengan kebutuhan-kebutuhannya yang khas, sehingga potensi-potensinya kurang dapat diwujudkan maka di samping dapat kehilangan bibit-bibit unggul bagi perkembangan negara dan bangsa Indonesia, anak-anak tersebut dirugikan bahkan dapat menjadi anak bermasalah, dan bisa jadi putus sekolah. ${ }^{2}$ Jelas bahwa anak supernormal membutuhkan didikan dan bimbingan secara khusus dan serius sehingga bisa mengikuti dan mengarahkan sesuai dengan kemampuan serta tahapan perkembangannya. Bahkan dalam Undang-Undang No. 2 tahun 2003 tentang sistem pendidikan nasional pada pasal 8 ayat 2 telah disebutkan bahwa: "warga negara yang memiliki kemampuan dan kecerdasan luar biasa berhak memperoleh perhatian khusus". Pasal ini menjadi dasar hukum bagi anak supernormal agar mereka mendapat perhatian lebih.

Di sini peneliti mencoba untuk mengamati salah satu sekolah di kota Madiun yang memiliki kelas unggulan (akselerasi) dengan latar belakang siswa yang memiliki kecerdasan di atas rata-rata (anak supernormal) dengan menggunakan pendekatan living values education program, yakni Madrasah Aliyah Negeri (MAN) 2 Kota Madiun. Para siswa kelas akselerasi MAN 2 Kota Madiun dikarantina dalam sebuah pesantren yang berada di dalam kompleks sekolah MAN 2 Kota Madiun. Dari hasil wawancara dengan pengelola kelas akselerasi, kebanyakan orang tua berkeyakinan bahwa anak yang mempunyai kecerdasan tinggi tidak mengalami kekhawatiran, sebab mereka mampu mengatasi masalahnya sendiri, orang tua memandang bahwa anak mereka memiliki segalanya. Padahal di sisi lain, anak supernormal tidak memiliki kemampuan untuk mencapai jalan yang benar tanpa bantuan orang lain, sebab mereka memerlukan bantuan dalam berkreasi dan menampilkan potensinya. Mereka tidak hanya memerlukan motivasi, tetapi lebih banyak

${ }^{2}$ Sutratinah Tirtonegoro, Anak Supernormal dan Program Pendidikannya (Jakarta: Bina Aksara, 1984),14 
memerlukan pengertian dan partisipasi serta dukungan. Orang tua dan masyarakat juga tidak terlalu memperhatikan anak-anak cerdas, tidak memberi sugesti, dan tidak membangkitkan kemampuan-kemampuan internal untuk mencipta dan berkreasi. Orang tua dan masyarakat memperlakukan mereka sama seperti yang lain, tidak ada yang beda maupun yang istimewa. Di sinilah anak-anak tersebut menemukan lingkungan yang seolah-olah tidak menghargai sebagaimana mestinya dan tidak mengenal kelebihan-kelebihan mereka. Akibatnya membuat mereka lemah atau guncang dan bisa membunuh faktorfaktor kreatifitas dan menghilangkan tanda-tanda kecerdasannya.

Keadaan ini diperparah dengan situasi orang tua yang kurang mengetahui tentang keadaan anaknya yang tergolong supernormal sehingga kalau anaknya berbuat hal-hal yang tidak masuk akal, ${ }^{3}$ orang tua tidak dapat mengerti. Bisa jadi orang tua hanya akan marah-marah, menghukum dan selalu menyalahkan anak tersebut. Oleh karena itu penting bagi orang tua untuk memahami dan mengetahui tanda-tanda kecerdasan dan ciri-ciri anak supernormal sehingga dalam kehidupan anak tersebut, orang tua akan mampu mengetahui dan bisa mengarahkan serta mendidiknya sesuai dengan tahapan perkembangan anak supernormal.

Hal-hal tersebut dapat dikatakan sebagai masalah yang unik untuk diteliti karena terjadi kesenjangan antara harapan dan fakta. Oleh karena itu, tidak

\footnotetext{
${ }^{3}$ Menurut tokoh pendidikan seperti Barbara Clark dan Seageo, anak berbakat memiliki karakter khusus sehingga memungkinkan ia memiliki masalah dengan lingkungannya. Anak berbakat memiliki keunggulan dalam aspek intelegensinya, yang ditandai dengan kecepatannya dalam menangkap dan mengingat informasi yang diberikan, menyukai pemecahan masalah, memiliki kemampuan konseptual, abstraksi dan sintesis yang baik, selalu berusaha mencari hubungan sebab akibat, memiliki perbendaharaan kata yang cukup banyak, memiliki ilmu pengetahuan yang luas, memiliki konsentrasi yang tinggi serta dapat menahan diri terhadap hal-hal yang menarik minatnya. Akan tetapi hal ini dapat menimbulkan kesulitan bagi anak tersebut untuk menyesuaikan diri dengan lingkungannya terutama teman sebaya. Anak menjadi tidak sabar terhadap orang lain dan tidak menyukai hal yang monoton, serta tugas-tugas rutin. Pemikiran mereka sering loncat-loncat dan tidak dimengerti oleh teman sebayanya. Mereka tidak menyukai sesuatu yang tidak jelas dan tidak masuk akal, senang menggunakan kata-kata untuk memanipulasi serta cepat bosan dengan teman sebaya. Kepribadian anak berbakat yang khas juga rentan menimbulkan konflik bagi lingkungannya. Biasanya mereka memiliki rasa ingin tahu yang besar dan keinginan yang kuat untuk selalu mencari jawaban atas sesuatu, yang mengakibatkan mereka sering menanyakan hal-hal yang dianggap kurang pantas atau tabu, sehingga membuat orang lain kewalahan. (Lihat "Warna-Warni Kecerdasan Anak" karangan Tim Pustaka Familia, (Yogyakarta; Kanisius, 2006) hal; 109-110)
} 
dapat dipungkiri bahwa yang terjadi seringkali bertolak belakang dengan teoriteori di atas. Di mana anak supernormal di MAN 2 Kota Madiun ini yang seharusnya mendapat perhatian dan pengertian atas sikap dan tindakannya yang mungkin berbeda dengan anak normal malah kurang mendapat perhatian dan pengertian dari orang tua maupun pihak yang belum atau kurang mengetahuinya.

Seorang anak tidak bisa dibiarkan tumbuh dan berkembang begitu saja tanpa ada yang merawat dan membimbing, karena anak bisa tumbuh liar tak terkendali sesuai dengan pola hidup dan lingkungannya. Pendidikan merupakan tanggung jawab dan kewajiban orang tua karena anak sebagai amanah Allah SWT. Oleh karena itu, orang tua tidak boleh menelantarkan kebutuhan-kebutuhan anak yakni kasih sayang, perlindungan, pendidikan, dan sebagainya. Sebagaimana sabda Rasulullah Saw:

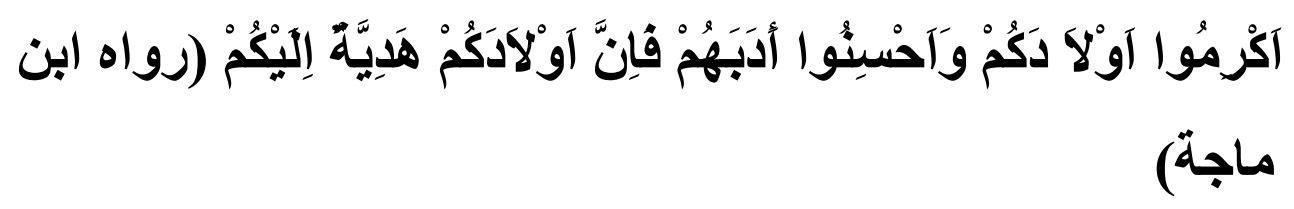

Artinya:"Hormatilah anak-anakmu sekalian dan perhatikanlah pendidikan mereka, karena anak-anakmu sekalian adalah karunia Allah kepadamu."4

Dalam hadis di atas, terkandung sebuah perintah dan seruan kepada orang tua untuk memperhatikan pendidikan dan mengarahkan anak-anak mereka serta menjadi sebuah amanah bagi orang tua atas terbentuknya akhlak mulia anak. Hal ini sejalan dengan prinsip yang terkandung dalam pendekatan Living Values Education Program (LVEP). Pendekatan LVEP merupakan sebuah model pendekatan karakter dengan nilai-nilai pendidikan yang komprehensif.

Agar terjadi keseimbangan dan kebahagiaan hidup di dunia dan akhirat pada anak supernormal, perlu penanaman pendidikan karakter yang sejalan dalam pendekatan Living Values Education Program (LVEP) agar dapat menginternalisasi sikap hidup akhlakul karimah secara kondusif. Anak

${ }^{4}$ Al-Khafiz Abi Abdillah Muh Bin Yazid, Sunan Ibnu Majjah (Beirut: Dar Al-Fikr tth, tt), 
supernormal merupakan kekayaan sumber daya insani yang tidak terukur nilainya. Mereka bukan hanya milik orang tuanya, melainkan milik masyarakat dan bangsa di mana mereka tumbuh dan berkembang sampai dewasa. Oleh karena itu, kekayaan yang besar ini semestinya tidak disia-siakan. Dengan memenuhi kemauan positif, memuji daya kreasi dan hasil kerja, dan mendidik serta mengarahkan langkah kehidupan mereka, sebagaimana dalam muatan pendekatan Living Values Education Program (LVEP), supaya ia tumbuh menjadi cendekiawan umat dan pimpinan masyarakat yang berkarakter dan berlandaskan pada ajaran agama yang hakiki.

Berangkat dari penjajakan awal di MAN 2 Kota Madiun pada tanggal 18 Maret 2018, diketahui bahwa guru-guru MAN 2 Kota Madiun melakukan upaya pendekatan pendidikan karakter (nilai) untuk anak supernormal di kelas akselerasi sebagaimana pendekatan dalam LVEP dalam setiap pola pembelajarannya. Oleh karena itu, peneliti ingin meneliti lebih dalam tentang bagaimana strategi, tahapan, dan pendekatan LVEP dalam mendidik anak supernormal yang mempunyai keunggulan kecerdasan untuk dapat membangun kehidupan bangsa. Selain itu, keingintahuan penulis tentang hasil penerapan Living Values Education Program dalam pengembangan anak supernormal di MAN 2 Kota Madiun, direalisasikan dalam penelitian lanjutan yang dilakukan dengan pendekatan observasi langsung di lapangan.

Data yang dikumpulkan sebagian berbentuk angka-angka (khusus data sekunder), sedangkan data primer berbentuk kata-kata, peristiwa-peristiwa, gambar-gambar, dan catatan-catatan. Oleh karena itu, penelitian ini tergolong pada jenis penelitian kualitatif. Menurut Bogdan dan Taylor dalam Moleong, ${ }^{5}$ penelitian kualitatif adalah penelitian yang menghasilkan data deskriptif berupa kata-kata tertulis atau lisan dari orang-orang dan perilaku yang dapat diamati.

Penelitian ini dilaksanakan di MAN 2 Kota Madiun karena letaknya strategis dan mudah dijangkau, dan utamanya karena merupakan salah satu sekolah yang membuka kelas akselerasi untuk anak-anak supernormal. MAN 2 2010), 4

${ }^{5}$ Moleong, Lexy J. Metodologi Penelitian Kualitatif (PT. Remaja Rosda Karya: Bandung, 
Kota Madiun merupakan Sekolah Menengah Atas Negeri yang terletak di tengah kota Madiun tepatnya di jalan Sumber Karya No. 08 Kota Madiun. Sumber data yang diperoleh adalah dari Kepala Sekolah MAN 2 Kota Madiun, 1 (satu) Guru PKN, 1 (satu) Guru PAI, 1 (satu) Pengelola Akselerasi, 1 (satu) Pengelola Asrama, 1 (satu) orang siswa dan 1 (satu) orang siswi dari kelas akselerasi MAN 2 Kota, serta observasi keadaan geografis dan catatan-catatan dokumen di MAN 2 Kota Madiun. Sebagai penunjang, beberapa elemen organisasi kemasyarakatan juga menjadi sumber melalui beberapa teknik, yaitu observasi, wawancara, dan dokumentasi.

\section{Nilai, Pendidikan Nilai, dan Tujuannya}

Menurut Gordon Alport, nilai adalah keyakinan yang membuat seseorang bertindak atas dasar pilihannya. Menurut Kuperman, nilai adalah patokan normatif yang memengaruhi manusia dalam menentukan pilihannya di antara cara-cara tindakan alternatif. Menurut Kuchlohn, nilai sebagai konsepsi (tersirat atau tersurat, yang sifatnya membedakan individu atau ciri-ciri kelompok) dari apa yang diinginkan, yang memengaruhi pilihan terhadap cara, tujuan antara, dan tujuan akhir tindakan. ${ }^{6}$

Mulyana menjelaskan bahwa pendidikan nilai adalah pengajaran atau bimbingan kepada anak agar menyadari nilai kebenaran, kebaikan, dan keindahan melalui keindahan, melalui proses pertimbangan nilai yang tepat dan pembiasaan bertindak yang konsisten. ${ }^{7}$ Menurut Sumantri, pendidikan nilai merupakan proses bimbingan melalui suri tauladan pendidik yang berorientasikan pada penanaman nilai-nilai kehidupan yang di dalamnya mencakup nilai-nilai agama, budaya, etika dan estetika menuju pembentukan anak yang memiliki kecerdasan spiritual keagamaan, pengendalian diri, kepribadian yang utuh, berakhlak mulia, serta keterampilan yang diperlukan dirinya, masyarakat dan negara. ${ }^{8}$

${ }^{6}$ Rohmat Mulyana, Mengartikulasikan Pendidikan Nilai (Bandung: Alfabeta, 2004), 9.

${ }^{7}$ Mulyana R, Mengartikulasikan Pendidikan Nilai (Bandung: Alfabeta, 2004), 11

${ }^{8}$ Sumantri, Pendidikan Nilai Kontemporer (Bandung: Program Studi PU UPI, 2007), 134 
Berdasarkan pendapat beberapa tokoh di atas, dapat disimpulkan bahwa pendidikan nilai merupakan suatu proses bimbingan kepada seorang individu yang di dalamnya meliputi nilai-nilai kehidupan yang diperlukan untuk kelangsungan hidup individu tersebut, masyarakat di sekitar, dan negara.

Menurut Hill (dalam Somad), pendidikan nilai ditujukan agar anak dapat menghayati dan mengamalkan nilai sesuai dengan keyakinan agamanya, konsensus masyarakatnya, dan nilai moral universal yang dianutnya sehingga menjadi karakter pribadinya. $^{9}$ Hal lain dikemukakan Sauri bahwasanya pendidikan nilai bertujuan untuk membantu anak agar memahami, menyadari, dan mengalami nilai-nilai serta mampu menempatkannya secara integral dalam kehidupan. Pendidikan nilai membimbing pemenuhan kehidupan manusia melalui perluasan dan pendalaman makna yang menjamin kehidupan yang bermakna manusiawi. ${ }^{10}$ Dalam proses pendidikan nilai, tindakan-tindakan pendidikan yang lebih spesifik dimaksudkan untuk mencapai tujuan yang lebih khusus. Seperti dikemukakan komite AFEID (Asia and The Pasific Programme of Education Innovation for Development), pendidikan nilai secara khusus ditujukan untuk: (a) menerapkan pembentukan nilai kepada anak, (b) menghasilkan sikap yang mencerminkan nilai-nilai yang diinginkan, dan (c) membimbing perilaku yang konsisten dengan nilai-nilai tersebut. Dengan demikian, tujuan pendidikan nilai meliputi tindakan mendidik yang berlangsung mulai dari usaha penyadaran nilai sampai pada perwujudan perilaku-perilaku yang bernilai. ${ }^{11}$

Dari beberapa pendapat mengenai tujuan pendidikan nilai di atas dapat diambil kesimpulan bahwa pendidikan nilai memiliki tujuan agar seorang individu dapat mengenal, mempelajari, memahami, dan berperilaku sesuai nilai-nilai kehidupan yang diinginkan oleh masyarakat.

9 Somad, Pengembangan Model Pembinaan Nilai-Nilai Keimanan dan Keberagamaan Siswa di Sekolah (Studi Kasus di SMAN 2 Bandung) (Disertasi Doktor pada SPs UPI: tidak diterbitkan, 2007), 22

${ }^{10}$ Sofyan Sauri dan Herlan Firmansyah, Meretas Pendidikan Nilai (Bandung: CV Armico, 2010), 7

\footnotetext{
${ }^{11}$ Mulyana R, Mengartikulasikan Pendidikan Nilai .., 120
} 


\section{Living Values Education Program (LVEP)}

\section{a. Pengertian Living Values Education}

Living Values Education (LVE) adalah sebuah model pendekatan bidang pendidikan yang menawarkan pelatihan dan metodologi praktis bagi para pendidik, fasilitator, pekerja sosial, orang tua, dan pendamping anak untuk membantu mereka menyediakan kesempatan bagi anak-anak dan orang muda menggali dan mengembangkan nilai-nilai universal. Program pendidikan nilai ini juga berlanjut sampai tahap bagaimana anak-anak dan orang muda dapat mengasosiasikan nilai tersebut dalam keterampilan sosial emosional dan intrapersonal interpersonal mereka sehari-hari.

LVEP berangkat dari asumsi dasar berikut:

1) Nilai-nilai universal mengajarkan penghargaan dan kehormatan tiap-tiap manusia. Belajar menikmati nilai-nilai ini menguatkan kesejahteraan individu dan masyarakat pada umumnya.

2) Setiap murid benar-benar memperhatikan nilai-nilai dan mampu menciptakan dan belajar dengan positif bila diberikan kesempatan.

3) Murid-murid berjuang dalam suasana berdasarkan nilai dalam lingkungan yang positif, aman dengan sikap saling menghargai dan kasih sayang, di mana para murid dianggap mampu belajar menentukan pilihan-pilihan yang sadar lingkungan. ${ }^{12}$

Berangkat dari asumsi dasar yang universal tersebut, kurikulum LVEP kemudian mencakup nilai-nilai kehidupan di mana kegiatannya bertujuan untuk perdamaian, rasa hormat, cinta, kerja sama, kebahagiaan, kejujuran, kerendahan hati, tanggung jawab, kesederhanaan, toleransi, kebebasan dan kesatuan. ${ }^{13}$ Nilai-nilai universal yang terintegrasi dalam tujuan Living Values Education Program (LVEP) sejalan dengan prinsip penyelenggaraan pendidikan di Indonesia, yaitu pendidikan diselenggarakan secara demokratis dan berkeadilan serta tidak diskriminatif dengan menjunjung tinggi hak asasi 2004), XV

${ }^{12}$ Diane Tillman Diana Hsu, Living Values Activities for Young Adults (Jakarta: Grasindo,

13 Diane Tillman, Living Values Activities for Children Ages 3-7 (New York: Health Communication, 2000). h. ii 
manusia, nilai keagamaan, nilai kultural, dan kemajemukan bangsa. ${ }^{14}$ Kurikulum LVE mencakup berbagai aktivitas bermuatan nilai untuk damai, menghargai, kasih sayang, kerja sama, kebahagiaan, kejujuran, kerendahan hati,tanggung jawab, kesederhanaan, toleransi, kebebasan, dan persatuan. Selain digunakan dalam pendidikan formal dan informal, LVE juga memiliki materi khusus untuk anak korban perang atau konflik, anak korban gempa bumi, anak jalanan, anak dalam rehabilitasi narkoba dan anak dalam penjara remaja.

Salah satu proses mendasar dalam program pelatihan LVE adalah tiap pendidik juga diajak untuk merefleksikan dan menggali nilai pribadi mereka, agar dapat menjadi pondasi dalam menciptakan suasana belajar yang berbasis nilai. LVE percaya bahwa nilai tidak diajarkan, melainkan ditangkap atau dirasakan. Murid belajar dari contoh yang diberikan pendidiknya. Oleh karena itu, sangat penting bagi tiap pendidik untuk menyadari dan terus menghidupkan nilai pribadi mereka, untuk dapat menjalani peran sebagai panutan ini secara positif.

Mendidikkan nilai harus berorientasi secara simultan pada processoriented dan content-oriented. Process-oriented adalah pembelajaran yang berorientasi pada pengembangan keterampilan penalaran, keterampilan sosial, serta keterampilan sikap dan nilai-nilai, sedangkan content-oriented adalah pembelajaran yang berorientasi pada upaya pengembangan materi pembelajaran agar lebih kaya, variatif, dan kontekstual. Hal ini penting dilakukan agar peserta didik tidak hanya dilibatkan pada aktifitas kognitif, tetapi juga mengembangkan keterampilan afektual dan partisipatorik. ${ }^{15}$

Dengan demikian dapar dimaknai bahwa Living Values Education Program (LVEP) adalah program nilai-nilai pendidikan yang komprehensif. Usaha global yang inovatif ini menawarkan pelatihan, metodologi praktis dan berbagai pengalaman aktivitas nilai untuk pendidik, fasilitator, orang tua dan

\footnotetext{
${ }^{14}$ Departemen Agama, Undang-Undang dan Peraturan Pemerintah RI tentang Pendidikan (Jakarta: Direktorat Jendral Pendidikan Islam Departemen Agama RI, 2006), 9.

${ }^{15}$ Doni Koesoema A, Pendidikan Karakter Setrategi Mendidik Anak di Zaman Global (Jakarta: Grasindo. 2007), 44
} 
pengasuh untuk membantu mereka memberikan kesempatan bagi anak-anak dan remaja untuk menggali dan mengembangkan nilai-nilai universal juga intrapersonal terkait keterampilan sosial dan emosional. Pendidik diminta untuk merefleksikan nilai-nilai mereka sendiri dan menciptakan suasana berbasis nilai. LVEP memiliki berbagai macam nilai yang diterapkan, meliputi perdamaian, menghormati, cinta, kerja sama, kebahagiaan, kejujuran, kerendahan hati, tanggung jawab, kesederhanaan, toleransi, kebebasan, dan kesatuan.

b. Strategi dan Tahapan Pendidikan Nilai dalam LVEP

Strategi dalam melaksanakan proses pendidikan nilai diawali dengan melihat kembali semua nilai-nilai yang telah dilaksanakan di lingkungan sekitar. Bagaimana pola interaksi antar individu, nilai-nilai apa yang tertempel di ruang publik, dan pertanyaan-pertanyaan sejenis digunakan untuk fokus terhadap usahausaha pengembangan suasana di mana nilai-nilai tersebut dilihat sebagai sebuah pendukung kurikulum yang vital. Dalam rangka menciptakan etos lembaga pendidikan yang positif, harus ada komitmen dari seluruh warga untuk menjadikan pendidikan berbasis nilai ini sebagai inti dari misi lembaga tersebut. ${ }^{16}$

Adapun langkah-langkah praktis dalam menjalankan proses pembelajaran pendidikan nilai di sekolah adalah sebagai berikut:

1) Guru menjelaskan pengertian dari nilai itu sendiri

2) Para siswa bercermin pada nilai tersebut dan mengkaitkannya pada tindakan mereka.

3) Para siswa akan mengimplementasikan nilai tersebut dalam tindakan mereka.

4) Pastikan para staff memberikan contoh nilai-nilai tersebut dari tingkah laku mereka. Pastikan bahwa nilai-nilai tersebut diajarkan secara implisit melalui setiap aspek di dalam kurikulum. ${ }^{17}$

\footnotetext{
${ }^{16}$ Muqowim, Materi Workshop; Disampaikan pada Workhsop tentang Pendidikan Nilai di STAIM Nglawak Nganjuk Jawa Timur pada tanggal 10-11 Februari 2018.

${ }^{17}$ Ibid..,
} 
Developing Values Schematic: The LVEP Method

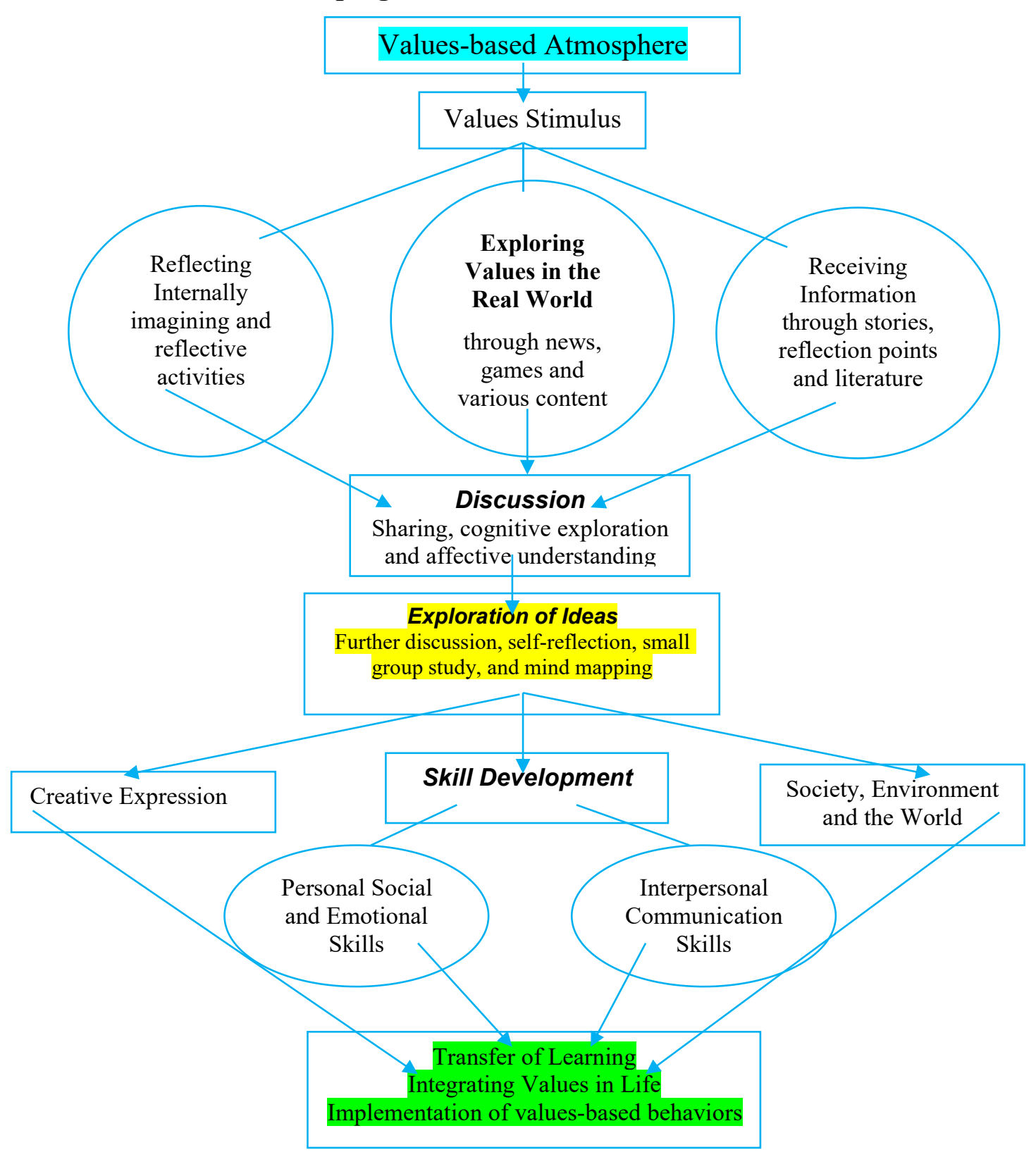

\section{Anak Supernormal}

Sebelum menguraikan tentang anak supernormal, terlebih dahulu akan penulis uraikan apa itu intelegensi dan IQ serta bagaimana cara pengukurannya, karena patokan anak supernormal dalam tulisan ini adalah tingkat tingginya intelegensi. Intelegensi atau kecerdasan merupakan suatu kemampuan tertinggi dari jiwa makhluk hidup yang hanya dimiliki oleh manusia dan diperoleh sejak 
lahir. Dengan demikian, potensi intelegensi mulai berfungsi memengaruhi waktu dan kualitas perkembangan individu dan apabila sudah berkembang, maka fungsinya semakin berarti bagi manusia, yakni akan memengaruhi kualitas penyesuaian dirinya dengan lingkungan. ${ }^{18}$

Para ahli mempunyai pengertian yang beragam tentang intelegensi yaitu:

\begin{tabular}{|c|c|}
\hline Nama Tokoh & Pendapat \\
\hline $\begin{array}{ll}\text { Anita } & \text { E. } \\
\text { Woolfolk } & \end{array}$ & $\begin{array}{l}\text { Menurut teori-teori lama, intelegensi itu meliputi tiga } \\
\text { pengertian, yaitu (1) kemampuan untuk belajar; (2) } \\
\text { keseluruhan pengetahuan yang diperoleh; (3) kemampuan } \\
\text { untuk beradaptasi secara berhasil dengan situasi baru atau } \\
\text { lingkungan pada umumnya. Selanjutnya Woolfolk } \\
\text { mengemukakan bahwa intelegensi itu merupakan satu atau } \\
\text { beberapa kemampuan untuk memperoleh dan menggunakan } \\
\text { pengetahuan dalam rangka memecahkan masalah dan } \\
\text { beradaptasi dengan lingkungan. }{ }^{19}\end{array}$ \\
\hline Alfred Binet & $\begin{array}{l}\text { Bersama Theodore Simon mendefinisikan intelegensi atas } \\
\text { tiga komponen yaitu (a) kemampuan untuk mengarahkan } \\
\text { fikiran atau mengarahkan tindakan; (b) kemampuan untuk } \\
\text { mengubah arah tindakan bila tindakan tersebut telah } \\
\text { dilaksanakan dan (c) kemampuan untuk mengeritik diri } \\
\text { sendiri atau melakukan autocriticism. }{ }^{20}\end{array}$ \\
\hline $\begin{array}{l}\text { David } \\
\text { Wechsler }\end{array}$ & $\begin{array}{l}\text { Menciptakan skala-skala intelegensi yang populer sampai } \\
\text { saat ini dan mendefinisikan intelegensi sebagai kumpulan } \\
\text { atau totalitas kemampuan seseorang untuk bertindak dalam } \\
\text { tujuan tertentu, berfikir secara rasional, serta mengahadapi } \\
\text { lingkungannya dengan efektif. }\end{array}$ \\
\hline
\end{tabular}

${ }^{18}$ Alisuf Sabri, Pengantar Psikologi Umum dan Perkembangan (Jakarta: Pedoman Ilmu Jaya, 1993),111

19 Samsu Yusuf, Psikologi Perkembanngan Anak dan Remaja (Bandung: Remaja Rosdakarya, 2002), 106

5 Saifudin Azwar, Pengantar Psikologi Intelegensi (Yogyakarta: Pustaka Utama, 2002),
${ }^{21}$ Ibid Hal., 7 


\begin{tabular}{|l|l|}
\hline S.C.Utami & $\begin{array}{l}\text { Secara umum bahwa intelegensi dapat dirumuskan: (a) } \\
\text { kemampuan untuk berfikir abstrak, (b) kemampuan untuk } \\
\text { menangkap hubungan dan untuk belajar dan (c) kemampuan } \\
\text { untuk menyesuaikan diri terhadap situasi-situasi baru. }\end{array}$ \\
\hline Woodworth & $\begin{array}{l}\text { Intelegensi erat hubungannya dengan intelek atau } \\
\text { pengetahuan, terutama berkenaan dengan kualitas dan } \\
\text { kegunaannya. Intelegensi itu sendiri merupakan intelektual } \\
\text { yang berdaya guna dan berhasil guna untuk menghadapi atau } \\
\text { bertindak dalam suatu situasi atau dalam menyelesaikan } \\
\text { masalah dimana dalam bertindak dan memecahkannya } \\
\text { tampak intelegen atau bodoh. Jadi orang yang intelegen } \\
\text { adalah orang yang mampu berbuat atau bertindak dengan } \\
\text { bijaksana, cepat, tepat dan berhasil. }{ }^{23}\end{array}$ \\
\hline
\end{tabular}

Dari beberapa pengertian di atas dapat penulis simpulkan bahwa intelegensi adalah suatu kemampuan mental yang dibawa individu atau manusia sejak lahir yang dapat digunakan untuk menyesuaikan diri dalam lingkungan yang baru dan untuk memecahkan problem-problem yang dihadapi dengan cepat dan tepat. Intelegensi berhubungan dengan bakat karena anak yang berbakat adalah anak dengan intelegensi sangat tinggi, intelegensi juga berhubungan dengan kreatifitas meski tidak dapat diidentifikasi menggunakan tes intelegensi, dan intelegensi juga berhubungan dengan prestasi yang bisa diukur sesuai variasi intelegensinya.

Intelegensi merupakan suatu konsep umum tentang kemampuan individu (seperti yang telah dijelaskan di atas) sedangkan IQ adalah hasil dari suatu tes intelegensi tertentu yang notabene yang hanya mengukur sebagian kecil dari intelegensi. ${ }^{24}$ IQ singkatan dari Intellegence Quotient menunjukkan ukuran atau taraf intelegensi atau kecerdasan seseorang. Dari hasil tes intelegensi IQ

22 S.C. Utami Munandar, Mengembangkan Bakat dan Kreativitas Anak Sekolah; Petunjuk Guru dan Orang Tua (Jakarta: Gramedia Widiasarana Indonesia, 1992), 19

${ }^{23}$ Alisuf sabri., 111

${ }^{24}$ Irwanto Dkk. Psikologi Umum (Jakarta: Gramedia Pustaka Utama, 1977), 171 
ini diperoleh dengan menggunakan rumus: hasil bagi umur mental dengan umur Cronologis atau kalender dikalikan seratus atau IQ $=(\mathrm{MA} / \mathrm{CA}) \mathrm{X} 100 .{ }^{25}$

MA singkatan dari Mental Age (usia mental) yang merupakan suatu norma pembanding pada kelompok usia tertentu. Misalnya pada kelompok anak-anak usia 8 tahun sebagian besar diantara mereka mampu menjawab dengan benar sebanyak 24 soal dalam tes, maka skor atau angka itu dijadikan norma untuk kelompok anak-anak usia 8 tahun, dan disebut usia mental 8 tahun. Bila seorang anak dalam mengerjakan tes yanng sama mampu menjawab dengan benar sebanyak 24 soal maka ia mempunyai usia mental 8 tahun. ${ }^{26} \mathrm{CA}$ singkatan dari Chronological Age (usia kronologis) yaitu usia anak sejak dilahirkan yang dapat dinyatakan dalam satuan tahun atau dalam satuan bulan. Misalnya apabila seorang anak yang berusia 8 tahun mampu menjawab dengan benar sebanyak 24 soal, maka ia dikatakan memiliki usia mental 8 tahun dan IQ-nya dihitung sebagai IQ $=(8 / 8) \times 100=100$. Seorang anak lain yang berusia 6 tahun tetapi sudah mampu menjawab dengan benar sebanyak 24 dalam tes yang sama akan memperoleh usia mental 8 tahun pula namun IQ-nya adalah $(8 / 6) \times 100=133 .^{27}$

Jelaslah bahwa apabila seorang anak mencapai usia mental yang sama dengan usia kronologisnya, maka ia akan mendapat IQ = 100 yang secara logis diartikan sebagai berintelegensi normal. Bila seorang anak memperoleh usia mental lebih tinggi daripada usia kronologisnya maka anak tersebut tergolong anak yang berintelegensi di atas normal, sebaliknya bila usia mental lebih kecil dari usia kronologisnya berarti intelegensinya di bawah normal. Demikianlah gambaran prinsip perhitungan IQ. ${ }^{28}$ Berdasarkan prinsip-prinsip perhitungan IQ tersebut, indikasi awal lahirnya konsep kecerdasan dinyatakan bahwa "semakin tinggi IQ seseorang maka semakin tinggi pula kecerdasannya".

Adapun pengertian anak supernormal yaitu anak yang mempunyai kecerdasan di atas anak-anak normal dan memiliki IQ di atas 110. Anak yang

\footnotetext{
${ }^{25}$ Alisuf Sabri.., Hal.113

${ }^{26}$ Saifudin Azwar..,. 52

${ }^{27}$ Ibid.,. 53

${ }^{28}$ Ibid
} 
tergolong supernormal yaitu meliputi anak genius memiliki IQ 140 ke atas, anak gifted atau very superior memiliki IQ 125-140, dan anak superior memiliki IQ 110-125.

Adapun batasan arti anak supernormal yakni :

a. Anak Genius, mewakili golongan anak yang memiliki IQ 140 ke atas.

Genius mempunyai arti anak yang memiliki tingkat intelegensi yang tinggi (IQ 140 ke atas) istilah ini juga dipakai terhadap seseorang yang memiliki bakat kemampuan luar biasa. ${ }^{29}$

Dalam bukunya Sri Rumini berjudul "Pendidikan Anak Genius" dikemukakan beberapa pendapat para ahli tentang batasan pengertian genius:

1) Orang awam banyak yang berpendapat bahwa semua anak yanng cerdas, cemerlang, berkemampuan tinggi adalah tergolong anak genius.

2) Ada yang menyamakan dengan talented (berbakat)

3) Ada yang menyamakan dengan Gifted atau Highly Gifted

4) Robert Woodworth dalam bukunya "Psychology" berpendapat bahwa anak genius adalah anak yang memiliki IQ di atas 140

5) Prof. Hollingwort berpendapat anak sudah berhak disebut genius kalau IQ-nya lebih dari 180

6) Dalam "The Wood Book Encyclopaedia" volume 8, halaman 87 dinyatakan kalau genius dipandang dari psikologi adalah seseorang dengan IQ 140 atau lebih

7) Ruth Strung mempunyai pendapat lain lagi terhadap para genius, menurut dia: kata genius sering diterapkan kepada individu yang mempunyai kapasitas istimewa (luar biasa) dan mampu menciptakan sesuatu yang sangat tinggi nilainya (mutunya). Jadi titik beratnya pada hasil ciptaannya, tidak hanya pada tingkatan intelegensinya. ${ }^{30}$

Dari berbagai pengertian di atas dapat disimpulkan bahwa anak genius adalah anak luar biasa cerdasnya sehingga dapat menciptakan sesuatu yang sangat tinggi nilainya, bila diukur dengan tes intelegensi IQ

\footnotetext{
${ }^{29}$ Depdikbud. Kamus Besar Bahasa Indonesia (Jakarta: Balai Pustaka, 1989) hal. 359

${ }^{30}$ Sutratinah Tirtonegoro, Anak Supernormal dan Program Pendidikannya., hal. 31-32
} 
mereka paling rendah 140 sedang yang paling tinggi dapat mencapai 200 lebih.

Para jenius lebih dari super cerdas ataupun sangat berbakat, mereka adalah orang-orang yang betul-betul hebat dan jauh mendahului masyarakat, bahkan dunia yang berbeda karena kontribusinya, sebagai contoh Beed Hoven, Picasso, Issac Newton Maria Currie, Leonardo Da Vinci dan sebagainya. ${ }^{31}$

\section{b. Anak Gifted/Very superior}

Anak gifted atau very superior memiliki tingkat kecerdasan tinggi bila diukur dengan tes intelegensi kurang lebih 125-140. Tingkat gifted berada di bawah tingkat genius dan di atas tingkat superior. Gifted adalah suatu terminologi bagi individu yang mempunyai IQ atau tingkat kecerdasan yang lebih dari normal yaitu IQ nya antara 120-140. Di samping itu mempunyai pula bakat yang istimewa atau menonjol antara lain berbakat dalam seni musik, drama, ketrampilan, dan keahlian memimpin masyarakat. $^{32}$

Dalam bukunya Samsu Yusuf yang berjudul "Psikologi Perkembangan Anak dan Remaja" dijelaskan bahwa gifted atau very superior ber-IQ 130-139 yaitu seorang yang cakap dalam membaca, mempunyai pengetahuan tentang bilangan yang sangat baik, perbendaharaab kata yang luas dan memahami pengertian abstrak. Faktor kesehatan, kekuatan, dan ketangkasan lebih menonjol dari pada anak normal. ${ }^{33}$

\section{c. Anak Superior}

Sesuai pada bagan penyebaran IQ anak superior menduduki IQ kurang lebih 110-125, merupakan golongan anak supernormal paling bawah. Anak superior dapat didefinisikan sebagai anak cerdas yang memiliki IQ kurang lebih 110-125, sehingga dapat mencapai prestasi belajar yang tinggi. ${ }^{34}$

\footnotetext{
${ }^{31}$ Joan Freeman, Utami Munandar, Cerdas dan Cemerlang (Jakarta, Pustaka, 2001) hal. 7

${ }^{32}$ Ibid., hal. 33

${ }^{33}$ Samsu Yusuf., 112

${ }^{34}$ Sutratinah Tirtonegoro., hal 33
} 
Menurut Samsu Yusuf, "superior” yaitu seseorang yang mempunyai IQ 120-129 kelompok ini sangat berhasil dalam pekerjaan sekolah atau akademik, mereka seringkali terdapat dalam kelas biasa, pimpinan kelas biasanya berasal dari kelompok ini. ${ }^{35}$

Demikianlah batasan-batasan arti anak yang supernormal yang pada intinya sama yaitu anak yang mempunyai kecerdasan tinggi tetapi dengan kemampuan yang berbeda-beda sehingga perlu dibedakan dalam mendidik dan mengajar mereka.

\section{Strategi dan Pendekatan Living Values Education Program (LVEP) dalam Pendidikan Anak Supernormal}

Berdasarkan hasil penelitian diketahui bahwa kelas akselerasi MAN 2 Kota Madiun menjadikan anak supernormal dengan mendidikkan dan menghidupkan nilai-nilai kehidupan kepada mereka. Secara umum diketahui bahwa strategi living values education program (LVEP) di kelas akselerasi MAN 2 Kota Madiun ini dilakukan dengan "pembiasaan, ceramah, praktek langsung, diskusi, unjuk kerja, pemberian tugas, dan kunjungan ke tempattempat kebesaran Allah, serta uswah hasanah". ${ }^{36}$

Pembelajaran anak supernormal yang dilakukan guru melalui penyisipan nilai-nilai dalam pada materi pelajaran yang dipelajari siswa, pemberian contoh sikap secara langsung oleh guru sebagai teladan bagi siswa, dan kalimat sederhana secara berulang-ulang agar siswa memahami pentingnya nilai/sikap tersebut. Menurut pandangan beberapa pakar terkemuka tentang pendidikan, beberapa pokok pikiran sebagaimana berikut kiranya layak untuk disimak untuk menjadi hal yang dapat dilakukan dalam rangkaian pembentukan sikap, karakter, dan akhlak mulia yang diharapkan semua orang tua.

a. Pembiasaan

Sebagaimana yang telah ada di MAN 2 Kota Madiun bahwa pembiasaan menjadi pembentuk nilai karakter siswa sehingga menjadikan mereka lebih

\footnotetext{
${ }^{35}$ Samsu Yusuf ., 112

${ }^{36}$ Wawancara dengan Bapak Dimyati (Guru al-Qur'an Hadist) di MAN 2 Madiun.
} 
memahami dan lebih peduli. ${ }^{37}$ Sikap malu bersikap egois dapat ditumbuhkan dalam diri setiap siswa sejak dini, sejak masa kanak-kanak, bahkan sebagaimana pandangan Ibnu Sina, sejak masa memilih jodoh. Dengan menanamkan kesadaran bahwa apapun yang dilakukan seseorang, baik atau buruk, akan membawa dampak kepada diri sendiri dan orang lain.

\section{b. Keteladanan (Values are caught)}

Teknik pendidikan karakter ini meskipun sering terlupakan dalam diskursus pendidikan merupakan salah satu teknik yang efektif dan dapat membuahkan hasil gemilang. Al-Abrasyi menulis bahwa keteladanan merupakan faktor utama dalam membentuk kebiasaan. Itulah sebabnya, Ibnu Sina menegaskan perlunya guru yang bertindak sebagai mursyid dan referensi hidup peserta didik yang dapat diteladani di mana kita bisa mengetahui bahwa manusia teladan terbesar dalam alam nyata adalah Nabi Muhammad saw.

Sebagaimana yang telah ada di MAN 2 Kota Madiun, bahwa guru agama juga menjadi teladan yang baik dalam pendidikan ibadah. Misalnya dalam hal shalat, guru agama biasanya yang menjadi imam dalam shalat dzuhur secara berjamaah. Orang-orang Arab dalam masa jahiliyyah telah melihat pada diri Muhammad saw. keistimewaan dan kemuliaan akhlaknya, sehingga beliau digelari "al-shaadiqu al-amiin" (yang benar lagi amanah). Orang tua di rumah, guru di madrasah, dan pemuka masyarakat baik formal (atasan) maupun informal di masyarakat, adalah pendidik yang menanamkan benih-benih pertama karakter mulia serta sikap dan perilaku determinan dalam diri anak didik.

\section{c. Sentuhan Kalbu melalui Kata Hikmah dan Dialog}

Di dalam menanamkan nilai-nilai, yang disentuh adalah rasa dan kesadaran manusia yang lebih dalam yang letaknya tidak di otak, tapi di hati dan kalbu. Hal ini tentunya terkait dengan aspek afektif dan psikomotorik. Ada suatu hal yang menarik untuk diaktualkan kembali dalam kaitannya dengan pendidikan nilai untuk menyentuh kesadaran manusia yang lebih dalam setelah hilang dalam peredaran di lembaga-lembaga pendidikan Islam; yaitu pelajaran

\footnotetext{
${ }^{37}$ Ibid..,
} 
aforisma (al-mahfudhaat) yang berisi sentuhan akan nilai-nilai belajar, kebenaran, kejujuran, kesungguhan, kehormatan, kedisiplinan, penghargaan atas ilmu pengetahuan, dan sebagainya yang tentunya laik untuk menumbuhkan sikap fleksibilitas, keterbukaan, ketegasan, pendangan ke depan, perrcaya diri, toleransi, kemandirian, dan seterusnya. Pelajaran berupa amtsaal (perumpamaan), hikmah, dan ungkapan-ungkapan betul-betul dapat menyentuh hati secara sangat efektif.

Manusia masa modern sebenarnya amat sangat membutuhkan sentuhan sentuhan pendidikan nilai-nilai sufistik dan falsafah hidup keagamaan yang lebih menyentuh. Oleh sebab itu, disarankan adanya seorang pendidik khusus yang menangani pendidikan nilai lewat teknik ini.

\section{d. Kisah-kisah}

Kisah-kisah yang mengandung nilai seperti al-Qiraat al-Rasyiidah yang banyak beredar di Indonesia atau semisalnya diharapkan dapat membentuk kebiasaan dan karakter mulia dan agung. Kisah-kisah serupa didapati juga dalam bahasa Inggris yang dibuat oleh Aesop. Kisah pendek kurang lebih 5-10 menit tentu dapat diinkorporasikan dalam satu mata pelajaran tertentu atau dikisahkan sebelum penyajian topik inti suatu mata kuliah. Sebagaimana diungkapkan oleh Ramayulis bahwa metode kisah ialah suatu cara mengajar dimana guru memberikan materi pembelajaran melalui kisah atau cerita. ${ }^{38}$ Cerita atau kisah akan menjadi pengalaman dan pelajaran yang berharga untuk disampaikan pada anak-anak agar mereka terinspirasi tokoh dalam kisah tersebut.

\section{e. Kedisiplinan}

Sebenarnya, kedisiplinan sangat efektif untuk membentuk sikap positif di kalangan peserta didik. Hal ini erat kaitannya dengan ketegasan yang proporsional tapi bukan kekerasan. Strategi menghidupkan nilai untuk menanamkan nilai-nilai (transfer of value) ke dalam diri peserta didik dilakukan secara kontinuitas dan berkesinambungan. Dengan adanya penanaman nilai-nilai kehidupan, maka setiap materi pelajaran yang

\footnotetext{
${ }^{38}$ Ramayulis, Ilmu Pendidikan Islam (Jakarta: Kalam Mulia, 2006), 196.
} 
disampaikan akan berbasis nilai dengan menyentuh berbagai aspek yang ditentukan. Penanaman nilai melalui agama tidak hanya dilakukan dalam madrasah-madrasah Islam saja, yang mata pelajaran agamanya bercabang menjadi banyak, namun juga dalam sekolah umum, seperti SMA, SMK, dan lain sebagainya.

Dalam menjalankan kelas akselerasi untuk anak supernormal, pendekatan yang dilakukan di MAN 2 Kota Madiun merupakan pendekatan holistik (terintegrasi dan tersinkronisasi) di mana pengembangan nilai karakter diintegrasikan dan diinterkoneksikan pada semua aspek yang ada dalam lingkungan madrasah. Untuk itu, perlu ada kolaborasi seluruh komponen yang ada di madrasah (siswa, guru, staff, komite, wali murid serta komunitas lainnya).

Model pengembangan pembelajaran berbasis nilai di kelas akselerasi MAN 2 Kota Madiun sebenarnya sudah lumayan, maka dari itu para guru tetap berusaha mengembangkannya dengan mengikuti diklat, workshop pengembangan bahan ajar, MGMP, membuat ringkasan dan hand out materi sendiri. ${ }^{39}$ Hal ini memang dari aspek penekanan mata pelajarannya itu, lebih ditekankan agar peserta didik menerapkan isi materi berbasis nilai dalam kehidupan sehari-hari. Para remaja setingkat SLTA ini rentan dengan perubahan gejolak jiwa dan pengaruh negatif dalam proses pencarian jati diri.

Penerapan nilai-nilai di madrasah sama penekanannya dengan bidang akademik pada umumnya. Model pendekatannya berupa dialog berperadaban, problem solving, dan sentuhan kalbu. Model pembelajarannya dengan demikian sifatnya aktif dan sugestopedik. Demikian sebagaimana disampaikan oleh Bapak Imron selaku pengelola asrama Pondok Pesantren Darul Rohmah MAN 2 Kota Madiun.

\footnotetext{
${ }^{39}$ Wawancara dengan Bapak Ridho (Pengelola Akselerasi) MAN 2 Kota Madiun.
} 


\section{Tahapan LVEP di MAN 2 Kota Madiun}

Tahapan menghidupkan nilai pada anak akselerasi MAN 2 Kota Madiun dimulai dari proses karantina, yang mana setiap siswa yang masuk pada kelas akselerasi pada tahun pelajaran 2017/2018 harus berada di asrama pondok pesantren "Darul Rohmah". ${ }^{40}$ Mereka selama pendidikan dua tahun di MAN 2 Kota Madiun harus berada di dalam asrama dengan maksud agar waktu intensif untuk belajar bisa benar-benar dimanfaatkan. Dari proses karantina akan diperoleh banyak manfaat terutama dalam pembentukan nilai-nilai kehidupan sehari-hari. Karena dalam asrama, anak diajarkan antri (makan, minum, mandi, dan menggunakan fasilitas asrama), selain antre anak diajak untuk menjalani kehidupan yang mandiri, jauh dari orang tua dan kerabat, menjalani kehidupan secara sederhana, menghindari bermewah-mewahan dan fokus serta sungguhsungguh untuk rajin belajar.

Tentunya tahapan-tahapan dalam menghidupkan nilai-nilai kehidupan siswa tersebut perlu pendampingan pendidik yang profesional. Menurut Munardji, untuk menjadi pendidik profesional tidaklah mudah, karena ia harus memiliki kompetensi keguruan, atau disebut kompetensi dasar (based competency) yang ditentukan oleh tingkat kepekaannya dari bobot potensi dan kecenderungan yang dimilikinya. ${ }^{41}$ Guru sebagai salah satu komponen dalam kegiatan belajar mengajar, memiliki posisi yang sangat menentukan keberhasilan pembelajaran, karena fungsi utama guru adalah merancang, mengelola, melaksanakan, serta mengevaluasi. Untuk mengetahui seberapa jauh pemahaman siswa terhadap suatu materi maka sebagai seorang guru yang profesional mengadakan evaluasi sebagai tolak ukur.

Tahapan pendidikan nilai juga masuk dalam proses belajar mengajar pada setiap langkah pembelajarannya. Karena itu, guru yang akan mengajar pasti memiliki dan menguasai bahan pelajaran yang akan disampaikan pada

\footnotetext{
${ }^{40}$ Wawancara dengan Bapak Imron (Pengelola Asrama) MAN 2 Kota Madiun.

${ }^{41}$ Munardji, Ilmu Pendidikan Islam (Jakarta: Bina Ilmu, 2004), 23.
} 
anak didik. ${ }^{42}$ Hand out materi akan mempermudah guru dalam menyampaikan materi yang banyak sehingga teringkas dalam hand out tersebut secara menyeluruh. Materi yang padat itu akan lebih baik jika seorang guru memiliki bahan ajar yang berupa hand out materi yang berasal dari pemikiran dan rangkuman guru berbasis nilai itu sendiri.

Oleh sebab itu penting seorang guru tahu, kreatif membuat hand out materi/modul, dan faham dengan bahan ajar berbasis nilai yang akan disampaikannya. Sebagaimana kita tahu dari data di lapangan bahwasanya para guru MAN 2 Kota Madiun juga berusaha untuk kreatif membuat hand out materi/modul pembelajaran baik dari ringkasannya sendiri, membuat slide/power point, ${ }^{43}$ yang bisa ditampilkan melalui OHP karena sebagian kelasnya juga sudah ada LCD proyektor, ${ }^{44}$ sehingga mempermudah dan mendukung guru untuk selalu kreatif dalam penyampaian materinya.

Jadi, di kelas akselerasi MAN 2 Kota Madiun tahapan-tahapan dalam pendidikan nilai dimulai dengan proses karantina di asrama, kegiatan belajar mengajar, kegiatan ekstrakurikuler, kegiatan di luar, serta kegiatan perlombaan. Para guru juga sudah tergolong kreatif dengan berbagai teknik menyampaikan materi ajar berbasis nilai kepada peserta didik. Dengan dukungan fasilitas yang cukup memadai karena sudah berbasis IT dalam penyampaian materi di kelas. Para guru di sini juga dituntut untuk belajar dan kreatif lagi dalam penyampaian materi ajar berbasis nilai karena memang sebagian siswa-siswi MAN 2 Kota Madiun memiliki kecerdasan otak di atas rata-rata sebagaimana di kelas akselerasi yang memiliki IQ 130 ke atas. ${ }^{45}$ Mereka yang memiliki otak di atas rata-rata sangat kritis, antusias dan aktif sekali di kelas khusus sehingga seorang guru yang akan mengajar di kelas khusus itu, ada tuntutan untuk lebih kreatif dan memiliki wawasan yang lebih tinggi daripada peserta didiknya. Dalam tahapan-tahapan menghidupkan nilai, bisa dilalui dengan mudah tanpa

\footnotetext{
42 Syaiful Bahri Djamarah dan Aswan Zain, Strategi Belajar Mengajar (Jakarta: PT. Rineka Cipta, 1996), hal. 50.

${ }^{43}$ Wawancara dengan Bapak Zaenuri (Waka Kurikulum) MAN 2 Kota Madiun.

44 Ibid...,

${ }^{45}$ Wawancara dengan Bapak Ari selaku Kepala Sekolah MAN 2 Kota Madiun.
} 
kendala yang berarti apalagi masing-masing anak sudah menyadari sendiri akan tanggung jawab dan kewajibannya sebagai seorang siswa dan juga karena kesungguhannya sehingga tahapan-tahapan itu bisa terlampaui dengan cepat.

\section{Hasil Penerapan LVEP terhadap Anak Supernormal}

Melalui Living Values Education Program (LVEP) dapat mewakili tanggung jawab orang tua dalam memastikan anak-anaknya memiliki kepribadian yang berbasis nilai luhur agama dan budaya. Pasalnya, pendidikan menghidupkan nilai dapat berlaku efektif terutama didasarkan pada keyakinan mendasar; Pertama, semua orang telah memiliki nilai kebaikan, baik dari Tuhan dan dari pengalaman sosial. Atas dasar ini, proses pendidikan tidak dilakukan dengan "memaksa" anak-anak untuk bernilai, melainkan mendorong setiap anak untuk mengapresiasi "nilai baik" pada dirinya, merefleksikannya, kemudian melahirkan nilai sesuai dengan potensi yang dimilikinya. Kedua, nilai tidak bisa diajarkan, nilai hanya bisa diteladani. Melalui keyakinan ini, LVEP dapat membantu para pendidik untuk melahirkan nilai dirinya (kesadaran nilai), kemudian dilengkapi keterampilan agar nilai-nilai itu bisa dinikmati bersama orang lain, khususnya anak didiknya.

Pentingnya pendidikan nilai menjadi suatu kebutuhan khusus yang tidak dapat dihindarkan lagi dalam dunia pendidikan saat ini. Sejalan dengan Undang Undang Republik Indonesia Nomor 20 Tahun 2003 pasal 3 tujuan pendidikan nasional adalah mengembangkan potensi peserta didik agar menjadi manusia yang beriman dan bertaqwa kepada Tuhan Yang Maha Esa, berakhlak mulia, sehat, berilmu, cakap, kreatif, mandiri, dan menjadi warga negara yang demokratis serta bertanggung jawab. Pendidik atau guru sebagai salah satu komponen dalam kegiatan belajar mengajar, memiliki posisi yang sangat menentukan keberhasilan pembelajaran, karena fungsi utama guru adalah merancang, mengelola, melaksanakan, serta mengevaluasi.

Sebagai program unggulan, Kelas Akselerasi MAN 2 Kota Madiun menerapkan Living Values Education Program (LVEP) dalam rangkaian aktifitas layanan pendidikan dan pengasuhannya untuk pembangunan karakter 
anak. Living Values Education Program (LVEP) adalah pendidikan nilai yang komprehensif, program pendidikan nilai yang memperhatikan kebutuhan anakanak, remaja, dan dewasa saat ini. Model teori dari program ini adalah mendorong terciptanya suatu suasana berbasis nilai dengan tujuan untuk memperbaiki kualitas pendidikan untuk manusia secara utuh.

\section{Penutup}

Dari hasil penelitian ini, maka penulis menyimpulkan beberapa hal, yaitu;

a. Strategi Living Values Education Program (LVEP) dalam pendidikan anak supernormal.

1) Melalui Pembiasaan di kelas Akselerasi MAN 2 Kota Madiun, di antaranya:

a) Pembiasaan Rutin, yaitu kegiatan yang dilakukan sesuai dengan jadwal yang telah disusun oleh MAN 2 Madiun.

b) Pembiasaan Spontan, Pembentukan perilaku memberi senyum, salam, sapa, membuang sampah pada tempatnya, budaya antri, mengatasi silang pendapat(pertengkaran),saling mengingatkan ketika melihat pelanggaran tata tertib sekolah, kunjungan rumah, kesetiakawanan sosial, kerja sama.

c) Pembiasaan Keteladanan, dalam bentuk perilaku sehari-hari, meliputi: berpakaian rapi, berbahasa yang baik, rajin membaca, memuji kebaikan dan keberhasilan orang lain, datang tepat waktu.

2) Melalui implementasi Kurikulum 2013 (K-13) yang sudah diintegrasikan dan dinamakan kurikulum differensiasi di kelas akselerasi. Strategi ini dikembangkan melalui penerapan K-13 disemua mata pelajaran karena K13 menuntut untuk melakukan pembelajaran berbasis tematik (terpadu).

3) Melalui memaksimalkan peran orang tua dalam memonitoring setiap kegiatan anak di lingkungan rumah.

b. Pendekatan Living Values Education Program (LVEP) dalam pendidikan anak supernormal. 
Pendekatan yang dilakukan guru pada anak supernormal di kelas akselerasi MAN 2 Kota Madiun merupakan pendekatan holistic (terintegrasi dan tersinkronisasi) di mana pengembangan nilai karakter diintegrasikan dan diinterkoneksikan pada semua aspek yang ada di lingkungan madrasah. Untuk itu, perlu ada kolaborasi seluruh komponen yang ada di madrasah, siswa, guru, staf, komite, para wali murid serta komunitas lainnya. Model pendekatannya berupa dialog berperadaban, problem solving, personal maupun kelompok, sentuhan kalbu, dan lain sebagainya.

c. Tahapan Living Values Education Program (LVEP) dalam pendidikan anak supernormal.

Tahapan menghidupkan nilai pada anak akselerasi MAN 2 Kota Madiun dimulai dari proses karantina, yang mana setiap siswa yang masuk pada kelas akselerasi pada tahun pelajaran 2017/2018 harus berada di asrama pondok pesantren "Darul Rohmah MAN 2 Kota Madiun ini tentunya dengan manfaat yang luar biasa didapat. Tahapan selanjutnya masuk pada ranah pembelajaran dan kegiatan belajar mengajar dalam/luar kelas yang mana dalam setiap langkah-langkah kegiatan belajar mengajar selalu disisipi pendidikan nilai. Selain pada tahapan ketika KBM, juga masuk pada tahapan ketika siswa mengikuti kegiatan ekstrakurikuler, kegiatan di luar, dan perlombaan untuk selalu menjunjung nilai-nilai yang terbaik.

d. Hasil penerangan Living Values Education Program (LVEP) dalam pendidikan anak supernormal

Hasil penerangan pendidikan menghidupkan nilai dapat berlaku efektif terutama didasarkan pada keyakinan mendasar; Pertama, semua orang telah memiliki nilai kebaikan, baik dari Tuhan dan dari pengalaman sosial. Atas dasar ini, proses pendidikan tidak dilakukan dengan "memaksa" anak-anak untuk bernilai, melainkan mendorong setiap anak untuk mengapresiasi "nilai baik" pada dirinya, merefleksikannya. Kedua, nilai tidak bisa diajarkan, nilai hanya bisa diteladani dan dipraktekkan. Melalui keyakinan ini LVEP dapat membantu para pendidik untuk melahirkan nilai dirinya (kesadaran nilai), 
kemudian dilengkapi keterampilan-keterampilan agar nilai-nilai itu bisa dinikmati bersama orang lain, khususnya anak didiknya.

\section{Daftar Referensi}

Abi Abdillah Muh. Bin Yazid, Al-Khafiz, Sunan Ibnu Majah, Beirut, Dar Alfikr, t.thn.

Alisuf Sabri, Pengantar Psikologi Umum dan Perkembangan: Jakarta, Pedoman Ilmu Jaya, 1993.

Azwar, Saifudin. Pengantar Psikologi Intelegensi, Yogyakarta: Pustaka Utama, 2002.

Bahri Djamarah, Syaiful, dan Aswan Zain, Strategi Belajar Mengajar, Jakarta: PT. Rineka Cipta, 1996.

Departemen Agama, Undang-Undang dan Peraturan Pemerintah RI tentang Pendidikan, Jakarta: Direktorat Jendral Pendidikan Islam Departemen Agama RI, 2006.

Depdikbud, Kamus Besar Bahasa Indonesia: Jakarta, Balai Pustaka, 1989.

Emzir, Metodologi Penelitian Kualitatif Analisis Data, Rajawali Press: Jakarta, 2011.

http://www.terwujud.com/2012/01/tujuan-program-pendidikan-nilainilai.html?m=1

Irwanto Dkk, Psikologi Umum: Jakarta, Gramedia Pustaka Utama, 1977.

Lexy J. Moleong, Metodologi Penelitian Kualitatif, PT. Remaja Rosda Karya: Bandung, 2010.

Koesoema A, Doni, Pendidikan Karakter Setrategi Mendidik Anak di Zaman Global Jakarta: Grasindo. 2007.

Ma'ruf Zurayk, Aku dan Anakku, Bimbingan Praktis Mendidik Anak Menuju Remaja: Bandung, Al-Bayan, 1998.

Mulyana, Rohmat, Mengartikulasikan Pendidikan Nilai, Bandung: Alfabeta, 2004.

Munardji, Ilmu Pendidikan Islam, Jakarta: Bina Ilmu, 2004.

Ramayulis, Ilmu Pendidikan Islam, Jakarta: Kalam Mulia, 2006.

Sabri, Ahmad, Strategi Belajar Mengajar dan Micro Teaching, Jakarta: Quantum Teaching, 2005.

Saifudin Azwar, Pengantar Psikologi Intelegensi: Yogyakarta, Pustaka Utama, 2002.

Sauri dan Herlan Firmansyah, Sofyan, Meretas Pendidikan Nilai, Bandung: CV Armico, 2010. 
Somad, Pengembangan model pembinaan nilai-nilai keimanan dan keberagamaan siswa di sekolah (studi kasus di SMAN 2 Bandung), Disertasi Doktor pada SPs UPI: tidak diterbitkan, 2007.

Sumantri, Pendidikan Nilai Kontemporer, Bandung: Program Studi PU UPI, 2007. S.C Utami Munandar, Perkembangan Bakat dan Kreativitas Anak Sekolah, Petunjuk Orang Tua: Jakarta, Gramedia Widia Sarana Indonesia, 1992.

Tillman, Diane, Living Values Activities for Children Ages 3-7, New York: Health Communication, 2000.

Tillman, Diane, Diana Hsu, Living Values Activities for Young Adults. Jakarta: Grasindo., 2004.

Tirtonegoro, Sutratinah, Anak Supernormal dan Program Pendidikannya: Jakarta, Bina Aksara, 1984.

Yusuf, Samsu. Psikologi Perkembanngan Anak dan Remaja, Bandung: Remaja Rosdakarya, 2002.

( 2020 pada penulis. Diterbitkan oleh LP2M INSURI Ponorogo, artikel jurnal ini dapat diakses secara terbuka dan memiliki lisensi CC-BY-SA (https://creativecommons.org/licenses/by-sa/4.0/). 